\title{
Ritual Maccera Pea (akikah) pada Masyarakat Massenrempulu di Desa Paladang Kec. Maiwa Kabupaten Enrekang
}

\author{
Nurul Fitrah Yani, Husni Bt Salam \\ Program Studi Administrasi Bisnis \\ Politeknik Informatika Nasional LP3I Makassar \\ nurulfitrahyani07@gmail.com, uniesalam53@gmail.com
}

\begin{abstract}
Abstrak
Penelitian ini bertujuan untuk mengetahui Semiotik Ritual Maccera Pea (Akikah) pada Masyarakat di Desa Paladang Kecamatan Maiwa Kabupaten Enrekang. Melalui penelitian ini diharapkan mampu memberikan gambaran kepada masyarakat luas dan pada pihak-pihak terkait bahwa kabupaten Enrekang yang lebih dikenal dengan kota Massenrempulu menyimpan sejuta pesona dalam kekayaan budaya. Pada penelitian ini peneliti menfokuskan pada analisis semiotik. yang berhubungan dengan ritual "Maccera Pea". Penelitian ini dilaksanakan di Desa Paladang Kecamatan Maiwa Kabupaten Enrekang. Subjek dalam penelitian ini adalah masyarakat yang menggelar acara "Maccera Pea".Jenis data yang digunakan adalah data kualitatif yang didapatkan melalui informan dari objek yang diteliti. Sumber data yakni data primer yang didapatkan secara langsung dan data sekunder dari pustaka yang berkaitan dengan permsalahan yang diteliti. Teknik pengumpulan data dengan metode observasi, wawancara dan dokumentasi. Teknik analisis data yakni (1) Mengumpulkan data yang bersumber dari beberapa referensi berupa buku dan wawancara dari informan (2) Mengklasifikasi dan menghubungkan dengan fenomena-fenomena yang ingin dipecahkan (3) Menganalisis data secara deskriptif berdasarkan teori yang digunakan (4)Menyimpulkan hasil analis data tentang Ritual Maccera Pea di Desa Paladang. Hasil penelitian menunjukkan bahwa prosesi yang dilakukan pada saat maccera pea merupakan prosesi yang telah dilakukan secara turun menurun oleh masyarakat Desa Paladang. Ada dua tahapan pada saat maccera pea yakni persiapan dan pelaksanaan prosesi adat. Setiap prosesi yang dilakukan mempunyai makna tersendri. Salah satu makna yang terkandung dalam tradisi ini, masyarakat Desa Paladang percaya bahwa setiap prosesi maccera pea sebagai wujud kerpercayaan atau keyakinan si anak yang diakikah akan memiliki kerberkahan hidup untuk menjalani kehidupan.
\end{abstract}

Kata kunci: Semiotik; Makna; Ritual

\begin{abstract}
This study aims to determine the semiotic ritual of Maccera Pea (Aqiqah) in the community in Paladang Village, Maiwa District, Enrekang Regency. Through this research, it is hoped that it will be able to provide an overview to the wider community and to related parties that Enrekang district which is better known as the city of Massenrempulu has a million charms in its cultural wealth. In this study the researchers focused on semiotic analysis. associated with the "Maccera Pea" ritual. This research was conducted in Paladang Village, Maiwa District, Enrekang Regency. The subjects in this study were the people who held the "Maccera Pea" event. The type of data used was qualitative data obtained through informants from the object under study. Sources of data are primary data which is obtained directly and secondary data from literature related to the problems under study. Data collection techniques using observation, interview and documentation methods. Data analysis techniques are (1) Collecting data from several references in the form of books and interviews from informants (2) Classifying and connecting with the phenomena to be solved (3) Analyzing data descriptively based on the theory used (4) Concluding the results of the analyst data about the Maccera Pea Ritual in Paladang Village. The results showed that the procession carried out at the time of maccera pea was a procession that had been carried out hereditary by the people of Paladang Village. There are two stages at the time of maccera pea, namely the preparation and implementation of the traditional procession. Every procession carried out has its own meaning. One of the meanings contained in this tradition, the people of Paladang Village believe that every maccera pea procession is a form of belief or belief that the child who is married will have the gift of life to live life.
\end{abstract}

Keywords:Semiotics; Mean; Ritual 


\section{Pendahuluan}

Indonesia merupakan negara yang kaya dengan khazanah budaya yang semestinya harus tetap dilestarikan. Sulawesi Selatan merupakan salah satu provinsi di Indonesia yang memiliki kekayaan budaya yang berlimpah dengan beragam keunikan, kekhasan dari setiap tradisi. Di Sulawesi Selatan yang didominasi oleh suku Bugis Makassar, syukuran akikah sangat kental dengan makna yang terkandung dari setiap proses ritual tersebut. Secara umum, kita dapat memahami bahwa kearifan lokal adalah pengetahuan yang dikembangkan oleh para leluhur dalam mensiasati lingkungan hidup sekitar mereka, menjadikan pengetahuan itu sebagai bagian dari budaya dan memperkenalkan serta meneruskan itu dari generasi ke generasi. Beberapa bentuk pengetahuan tradisional itu muncul lewat cerita-cerita, legenda-legenda, nyanyian-nyanyian, ritual-ritual, dan juga aturan atau hukum setempat.

Suku bugis dan Makassar merupakan suku yang terbanyak di Sulawesi Selatan. Salah satu kegiatan syukuran yang biasa dilakukan yaitu syukuran hakikah yang mana masih sangat kental dengan makna kelangsungan dalam upaya penyelamatan di sekitar masyarakat dan mengandung pappasang atau pesan moral sebagai investasi jangka panjang untuk setiap generasi selanjutnya. Masyarakat menyakini bahwa sebuah tradisi harus dilakukan agar kelak kelahiran sebuah generasi baru tidak merusak atau membebani alam sekaligus menjaga tradisi gotong royong dan memelihara kekerabatan. Maka dari itu, dapat diketahui bahwa kearifan lokal adalah pemahaman yang disebar oleh para leluhur dalam menjaga lingkungan hidup sekitar mereka, dan menjadikan bahwa sebuah tradisi dari para leluhur harus dilestarikan agar kelak para generasi selanjutnya dapat memahami arti sebuah tradisi.

Di Indonesia, ritual aqiqah ini kerap dipadukan dengan tradisi dan kearifan lokal sehingga menjadi sebuah peristiwa yang menarik dan penuh makna. Salah satu ritual yang unik dan menarik adalah acara ritual tradisi Maccera Pea di desa Paladang atau lebih umum disebut dengan akikah. Tidak dapat dipungkir bahwa dalam kehidupan beragama manusia memiliki tradisi dalam segalam tindakan beragama (Marhani, 2018). Salah satu hal yang wajib dilakukan dalam agama Islam ketika lahirnya seorang anak yaitu aqiqah. Ini merupakan acara adat yang melambangkan rasa syukur siempunya hajat kepaada Tuhan. Ritual 'Maccera Pea' dilakukan setiap kali ada kelahiran bayi baru dalam setahun dan terdiri dari berbagai bentuk sesuai dengan kebutuhan momentumnya serta berhubungan dengan perjalanan hidup manusia yakni kelahiran, perkawinan dan kematian.

Penyelenggaraan Maccera Pea ini pada dasarnya memiliki keterkaitan erat dengan aspek religi (agama) secara vertikal serta hubungan sosial kemasyarakatan dalam arti luas. Dari sudut pandang religi (agama) prosesi Maccera Pea dipandang sebagai medium penghubung antara kehidupan manusia yang nyata dengan sang pencipta (dunia gaib). Pada Aspek sosial, tradisi maccera pea memiliki multifungsi baik fungsi sosial, agama, ekonomi dan aspek-aspek kehidupan lainnya sekaligus memiliki kandungan makna yang sangat.

\section{Kerangka Teori}

Semiotik adalah ilmu tentang tanda-tanda, semiotik itu mempelajari sistem-sistem, aturan-aturan, konvensi-konvensi yang memungkinkan tanda-tanda tersebut mempunyai arti. Tanda mempunyai dua aspek yaitu penanda (signifier) dan petanda (signifie). Preminger dalam (Pradopo, 1999) mengatakan bahwa salah satu bentuk penanda sebagai bentuk formalnya yang menandai sesuatu yang ditandai oleh petanda itu yaitu sebagai suatu arti. Kajian mengenai semiotik tahapan prosesi pada dasarnya saling berhubungan dengan pelaku dan benda atau alat yang digunakan. Dalam hal ini, pada setiap tahapan

Halaman | 705 
prosesi tentu melibatkan pelaku dan peranannya serta menggunakan benda-benda yang ditafsirkan makna semiotiknya (Amandani et al., n.d.)

Diketahui bersama bahwa tanda ada berbagi jenis dalam kehidupan kita. Semua tanda yang kita lihat mempunyai makna yang dapat dimaknai secara subjektif. Menurut Pierce dalam (Yoyon Mudijiono, 2011) bahwa tanda dapat dibedakan menjadi tiga bentuk yakni ikon sebagai wujud tanada dan penanada yang bersifat alamiah. Contohnya gambar kucing sebagai penanda untuk menandai kucing sebagai artinya. Yang kedua indeks, yang merujuk pada definisi kausal atau lebih dikenal sebagi hubungan sebab akibat antara penanda dan petandanya. Misalnya sebuah asap menandai bahwa ada api. Ketiga, simbol yakni bertolak belakang dengan ikon. Simbol sebagai penanda dan petanda yang tidak berhubungan dengan hal-hal yang berkaitan dengan alamiahnamun lebih berisfat manasuka (arbitrer). Contoh kata "Ibu" adalah simbol artinya ditentukan oleh konvensi atau pilihan masyarakat bahasa (Indonesia).

Simbolisme pada prinsipnya bukan merupakan hal yang baru dalam karya sastra dan juga pada realita yang ada di masyarakat (Agustina, 2017). Misalnya saja simbolisme bunga teratai, bunga yang hanya bisa hidup di air dan lumpur yang kotor, tampak sekilas orang melihat bahwa bunga itu tidak memiliki keistimewaan saat belum mekar. Namun, setelah mekar dan memunculkan wujud aslinya, bunga teratai memperlihatkan keindahannya dipermukaan walaupun hidupnya diperairan yang kotor. Bunga teratai yang kebanyakan berwarna merah ini melambangkan keadaan asli hati, yakni cinta, kasih sayang, nafsu, emosi dan lainnya yang berkaitan dengan hati. Masyarakat daerah pedesaan meyakini bahwa bunga teratai merah jika diberikan kepada seseorang melambangkan keterbukaan hati seseorang yang memberinya.

Bahasa adalah sistem bunyi tanda yakni kedudukannya lebih tinggi. Karya sastra juga merupakan sistem tanda yang berdasarkan kesepakatan masyarakat, karena sastra merupakan tanda yang lebih tinggi tingkat, misalnya sebelumnya, mengkaji nilai semiotik tingkat yang kedua. Meskipun sastra itu dalam semiotik tingkatanya lebih tinggi dari pada bahasa, namun sastra tidak bisa lepas pula dari sistem bahasa, dalam arti sastra tidak lepas dari sistem konvensional bahasa.

Pengertian makna dalam sense dibedakan dari (meaning- bahasa inggris) di dalam semantik. Menurut (Kridalaksana, 2012) bahwa makna merupakan maksud pembicaraan, pengaruh suatu bahasa dalam pemahaman resepsi atau prilaku manusia; hubungan dalam arti kepadanan antara bahasa dan luar bahasa atau antara ujaran dan semua lambang yang ditujukannya, dan cara menggunakan lambang-lambang bahasa. Menurut Palmer dalam (Djajasudarma, 2013) bahwa makna hanya menyangkut intra bahasa. Menurut Samsuri mengungkapkan adanya garis hubungan antara:

$$
\text { makna --------- ungkapan ---------- makna }
$$

Mempelajari makna pada hakikatnya berarti bagaimana setiap pemakai bahasa dalam suatu masyarakat bahasa dapat saling mengerti. Dalam hal ini, untuk menyusun sebuah kalimat yang dapat dimengerti, sebagian pemakai bahasa dituntut agar mentaati kaidah gramtikal, sebagian lagi tunduk pada kaidah pilihan kata menurut sistem leksikal yang berlaku di dalam suatu bahasa.

Makna sebuah kalimat sering kali tidak bergantung pada sistem gramatikal dan leksikal saja,tetapi tergantung pada kaidah wacana. Makna sebuah kalimat yang baik pilihan katanya dan susunan gramatikalnya sering tidak dapat dipahami tanpa memperhatikan hubungannya dengan kalimat lain dalam sebuah wacana. 
Jurnal Onoma: Pendidikan, Bahasa dan Sastra PBSI FKIP Universitas Cokroaminoto Palopo Volume 6 Nomor 2
ISSN 2443-3667 (print)

ISSN 2715-4564 (online)

\section{Metode Penelitian}

Penelitian ini adalah penelitian deskriptif kualitatif yakni penelitian yang berorientasi pada analisis semiotik pada ritual Maccera Pea di Desa Paladang. Penelitian ini diadakan di Desa Paladang Kec. Maiwa Kabupaten Enrekang Sulawesi Selatan. Sumber data dalam penelitian ini terdiri dari, a) data primer adalah data yang didapat dengan cara turun langsung dilapangan atau lokasi penelitian b) data Sekunder adalah data yang diambil atau data yang didapat dari pustaka yang berkaitan dengan permasalahan yang diteliti. Teknik pengumpulan data dilakukan dengan tiga cara :

1. Observasi merupakan teknik pengumpulan data, dimana peneliti melakukan pengamatan secara langsung ke objek penelitian untuk melihat dari dekat kegiatan yang dilakukan

2. Wawancara mendalam merupakan proses menggali informasi secara mendalam, terbuka, dan bebas dengan masalah dan fokus penelitian dan diarahkan pada pusat penelitian.

3. Dokumentasi yaitu kegiatan pengumpulan data melalui berbagai sumber data yang tertulis, baik yang berhubungan dengan masalah kondisi objektif, juga silsilah dan pendukung data lainnya.

Teknik analisis data yang telah diperoleh yang bersumber dari buku-buku, dan hasil wawancara dengan para nara sumber dari tokoh-tokoh masyarakat dikumpul kemudian diklasifikasikan dan dihubungkan dengan fenomena-fenomena yang ingin dipecahkan dalam rumusan masalah. Setelah itu, data dianalisis menggunakan metode deskripsi kualitatif sehingga hasil dari analisis data tersebut mampu menjawab atau memecahkan fenomena-fenomena yang diangkat pada masalah penelitian.

\section{Hasil dan Pembahasan}

\section{Bentuk Ritual Maccera Pea}

Ritual Maccera Pea merupakan ritual yang dilaksanakan sebagai acara syukuran untuk penyambutan bayi yang baru lahir yang ditandai dengan pemotongan rambut. Pada ritual maccera pea prosesi ini memiliki elemen simbol keagamaan yang sarat makna unsur-unsur semiotik ritual religi. Unsur-unsur simbol juga dapat diamati. dari pelaku ritual, jenis peralatan dan benda yang digunakan, tahapan prosesi termasuk model komunikasi budaya dan interaksi sosial yang berlangsung dalam penyelenggaraannya.

\section{a. Persiapan Maccera Pea}

Dalam prosesi persiapan setidaknya terdapat tahapan penentuan waktu pelaksanaan (hari atau bulan) baik ada prosesi penentuan tanggala atau mempersiapkan segala sesuatu yang berhubungan dengan prosesi, termasuk mempersiapkan bayi yang akan dipotong rambutnya serta prosesi mengundang warga untuk menghadiri prosesi. Penentuan waktu dilakukan oleh pemangku adat atau lebih dikenal dengan kapala ada'. Pihak keluarga penyelenggara acara tidak bisa memilih sendiri waktu yang diinginkan karena harus terlebih dahulu dirapatkan dengan para pemangku adat. ,

Selanjutnya, pada tahap persiapan sebelum pelaksanaan maccera pea dilakukan dengan menyiapkan peralatan dan perlengkapan seperti makanan khas, buah-buahan dan beberapa sarung. Setelah itu, pihak keluarga pelaksana acara akan mengunjungi kuburan para leluhur sebagai tanda akan dimulainya suatu hajatan atau acara. Hal ini, seperti yang disampaikan oleh informan kepada peneliti:

"iya kela meloki, mangacara maccera atau mappabotting tattaki inja mabolo' kaburu iyasanga maminta izing to leluhurta"

Hasil wawancara oleh peneliti diartikan yakni kegiatan mengunjungi leluhur yang telah tiada adalah kewajiban karena salah satunya untuk meminta restu atau izin kepada 
para leluhur agar pelaksanaan hajatan atau suatu acara dapat terlaksana dengan baik. Berdasarkan hasil wawancara peneliti dengan informan, data yang ditemukan bahwa ketika suatu acara atau hajatan dilaksanakan tanpa melalui ritual ke pemakaman leluhur maka acara tersebut tidak akan berlangsung dengan baik karena tidak menyertakan atau meminta izin kepada para leluhur terutama leluhur yang masih satu keturunan.

\section{b. Prosesi Pelaksanaan Maccera Pea} berikut:

Selanjutnya pada tahap prosesi pelaksanaan Maccera Pea dapat diuraikan sebagai

\section{1) Penyembelihan hewan (kambing dan ayam)}

Berdasarkan informasi yang didapatkan peneliti bahwa ayam merupakn hewan yang wajib disembelih selain kambing. Penyembelihan kambing dilakukan terlebih dahulu, setelah itu dilanjutkan dengan penyembelihan ayam. Biasanya jumlah kambing disesuaikan dengan jenis kelamin bayi yang akan dihakikah. Jumlah ayam yang disembelih juga sesuai dengan berapa jenis hajatan yang dibuat oleh sipembuat acara. Penyembelihan ini dilakukan oleh pemangku adat atau orang yang telah diberi kepercayaan untuk menyembelih hewan.

\section{2) Pelaksanaan Maccera Pea}

\section{a)Mabaca-baca}

Selanjutnya, inti dari acara ini adalah pada pelaksanaa Maccera Pea yakni:

Para tamu hadir duduk melingkar bersama dengan para pemangku adat. Di tengahtengah lingkaran tersebut ada beberapa sajian khusus seperti ayam yang dimasak santan tanpa meletakkan penyedap rasa seperti garam. Kemudian ada beberapa jenis sokko yang diberi pewarna. Hasil wawancara peneliti dengan informan yakni:

"nda na dibengan pe"je sanga untuk dipakande sassuran"

Dari hasil wawancara tersebut dapat diartikan bahwa ayam yang dimasak santan tidak berikan penyedap rasa atau garam karena menurut kepercayaan masyarakat Desa Paladang makanan itu diperuntukkan buat sassuran dalam artian masyarakat percaya bahwa setiap bayi yang lahir ke muka bumi ini pasti memiliki saudara kembar. Jadi, masakan ayam yang tidak diberikan penyedap rasa itu karena untuk saudara kembar sibayi. Tidak diberi penyedap rasa karena anak yang baru lahir memang makanannya tidak berikan berbagai jenis penyedap makanan.

Dihadapan sesepuh akan dihidangkan makanan yang telah ditata dalam sebuah nampan yang orang Bugis menyebutnya Bakik dilengkapi dengan tungku kecil yang disebut dupa-dupa yang berisikan bara api. Nantinya bara api tersebut akan ditaburi bubuk berwarna putih sehingga menghasilkan asap yang berbau menyengat. Disitulah sesepuh atau pemangku adat memulai Ma'baca-baca.

\section{b)Barasanji}

Barasanji adalah suatu doa, pujian, dan penceritaan riwayat Nabi Muhammad S.A.W. yag dilafalkan dengan suatu irama atau nada yang biasa dilantunkan ketika kelahiran, khitanan, pernikahan dan maulid Nabi Muhammad s.a.w. isi barasanji berisi tentang kehidupan Muhammad yang disebutkan berturut-turut yaitu silsilah keturunannya, masa kanak-kanak, remaja, pemuda hingga diangkat menjadi rasul. Di dalamnya juga mengisahkan sifat-sifat mulia yang dimiliki Nabi Muhammad s.a.w. dan berbagai peristiwa untuk dijadikan teladan umat manusia.

Masyarakat yang membaca massukiri tidak ditentukan berapa jumlahnya karena semakin banyak yang membacakannya berarti semakin banyak yang mendoakan bayi tersebut. Pembacaan masukiri ini dapat dilakukan oleh laki-dan perempuan secara bergantian. Menurut informan yang saya wawancarai bahwa massukiri merupakan hal atau ritual yang wajib dilaksanakan pada suatu acara syukuran seperti hakikah dan pernikahan.

Halaman | 708 


\section{c) Maccera}

Inti dari pelaksanaan ini adalah pada saat pemotongan rambut bayi. Ketika bacaan massukiri sudah berada pada bagian pertengahan maka, orang tua sibayi akan mengendong sibayi untuk diarakkan mengelilingi pemangku adat dan para tamu. Buah kelapa sebagai tempat penyimpanan rambut bayi juga menjadi sebuah tradisi pada masyarakat Desa Paladang.

\section{d)Sokko}

Sokko merupakan bahasa Massenrempulu yang berarti beras ketan, sedangkan pattarupa berarti empat macam. Sokko pattarupa merupakan beras ketan yang disajikan dalam sebuah piring makan dan dibagian tengah sokko tersebut diletakkan sebutir telur kampung yang telah direbus. Sokko ini diapitkan, sokko bolong berimpit dengan sokko pute, serta sokko cella berimpit dengan kuning, kemudian di atas sokko yang berimpitan diletakkan tallo (telur). Sokko pattarupa memiliki empat macam warna, yakni hitam, kuning, merah dan putih. Sesuai wawancara yang saya dapatkan yakni:

"Sokko pattarupa dikabua untuk napangiarangki pajajianta. Itu sokko empat macam karena hidupta memangmi penuh warna dan haruski tau juga dari mana asal usulta".

Berdasarkan hasil wawancara tersebut, informan mengatakan bahwa. Beras ketan sebagai wujud kehidupan manusia. Masyarakat Desa Paladang mempercayai bahwa empat macam warna tersebut sebagai asal muasal penciptaan manusia dan leluhur mereka sudah melakukan hal tersebut dan harus mereka ikuti.

\section{e. Balasuji}

Bala berarti pagar suji berarti sesajian. Balasuji adalah pagar sesajian yang terbuat dari bambu yang di dalamnya terdapat sebuah periuk yang berisi sokko, telur, buah kelapa, pisang, nangka dan buah-buahan lainnya. Di dalam balasuji juga disertakan dengan kalosi, ketupat. Hal ini sebagaimana yang didapatkan pada saat wawancara yakni:

"Isinna itu balasuji utti, panasa, inyio, sokko sibawa tallo dondeng kampung, deppa pitu rupa. Kalosi sibawa lappa-lappa wajib di anna"

Dari wawancara tersebur dapat diartikan bahwa, balasuji itu mengandung beberapa jenis makanan dan buah-buahan yakni pisang, nangka, kelapa dan juga ayam kampung yang telah direbus. Selain itu juga ada juga buah pinang atau lebih dikenal dengan kalosi dan juga ketupat yang bentuknya memanjang atau masyarakat massenrempulu menyebutnya dengan lappa-lappa.

\section{f. Memakan sesajian}

Memakan sesajian bagi orang terdahulu merupakan tradisi ketika tujuh bulanan kandungan ibu untuk anak pertama, dan kemudian dilanjutkan lagi pada saat acara hakikah. Orang tua dan anak memakan sesajian yang disiapkan dalam sebuah nampan makanan yang terdiri dari tujuh macam kue bugis seperti. Hal ini sebagaimana dalam wawancara yang peneliti dapatkan yakni:

"Biasanya kue tujuh macam wajib disetiap acara. Itu kue tradisional semuanya. Sedikit- sedikitji kami bikin yang penting ada tujuh macam bentuknya. Ada siwalla cucuru", gallang- gallang, onde-onde, deppa oto, deppa jompo dan buah sappang".

Dari hasil wawancara yang didapatkan dari informan yakni, informan mengatakan bahwa kue tradisional yang mereka buat wajib dihidangkan untuk dicicipi oleh bayi dan orang tua sibayi. Kue tradisional tersebut dibuat dengan tujuan jenis kue yang berbeda.

\section{g. Mappanoong di Salu}

Tahap terakhir pada prosesi maccera pea ini adalah membawa balasuji ke sungai. Balasuji tersebut diisi dengan berbagai varian makanan dan buah-buahan seperti sokko dan telur. Mappanoong di Salu artinya balasuji dibawa kemudian dialirkan ke sungai.

Halaman | 709 
Pelaksanaan mappanoong tidak harus dilaksanakan di sungai. Namun dapat juga dilakukan di tempat lain selama tempat itu masih terdapat air yang dapat digunakan untuk mappanoong. Hal ini seperti yang disampaikan oleh informan:

“.....injaki salu mabawa balasuji.jika taen salu, bisa unna ki dibolata mappagau jika inda didapi. Bisa unna di wai tasi. Jika purami dipanoong tu balasuji di salu, dipanndiomi indon tu bija.

Dari hasil wawancara tersebut dapat diartikan bahwa, ritual mappanoong tidak harus dilakukan disungai bisa juga dilakukan saja di rumah jika memang berhalangan. Selanjutnya jika setelah melakukan mappanoong dengan mengalirkan balasuji ke sungai maka ibu sibayi dimandikan sebagai wujud pensucian dan penyampaian kepada tuhan bahwa sianak telah diislamkan sesuai dengan tradisi yang dijalankan.

\section{Makna Ritual Maccera Pea}

Makna ritual maccera pea berkaitan erat dengan kehidupan sibayi sebelum melangkah menuju masa remajanya dan menuju ke kehidupan selanjutnya.

\section{a. Persiapan maccera pea}

Pemilihan tanggal sebagai hal wajib dilakukan sebelum sebuah acara dimulai. Penentuan hari baik tidak hanya pada kegiatan sehari-hari namun juga seperti pada saat membeli kendaraan seperti mobil dan motor. Begitu pula dengan pemilihan tanggal pada saat maccera pea. Semua kegiatan dimaknai sebagai kegiatan yang baik sehingga diperlukan penentuan tanggal yang baik juga. Hari yang baik yakni hari yang di dalamnya terdapat kualitas waktu yang dianggap baik sehingga memungkinkan untuk membuat suatu acara.

Makna mengunjungi pusara leluhur sebelum acara maccera pea dimulai yakni untuk memelihara kontak dan komunikasi kepada leluhurnya agar jalan hidup menjadi terang. Tradisi seperti ini mutlak masyarakat Desa Paladang lakukan sebagai pondasi dan pegangan hidup masyarakat Desa Paladang. Hal ini juga sebagai wujud bahwasanya masyarakat Desa Paladang masih mengingat, memuliakan serta mendoakan para lelulur yang dianggap dapat mendatangkan pengaruh ketentraman jiwa bagi sipembuat acara.

\section{b. Prosesi Pelaksanaan Maccera Pea}

1. Penyembelihan hewan (Kambing)

Jenis kambing yang disembelih sesuai dengan jenis kelamin sibayi dan mengikuti syariat Islam. Jatuhnya hari pelaksanaan hakikah memiliki berbagai pendapat. Pelaksanaan hakikah bukan hanya dilaksanakan pada saat sibayi berusia 7 hari namun juga bisa pada saat usia ke 21 hari, 40 hari dan tidak memiliki batas sesuai kapan kemampuan orang tua si bayi untuk melaksanakan hakikah.

Simbol makna penyembelihan kambing pada saat hakikah merupakan salah satu bentuk wujud rasa syukur kepada Tuhan. Makna yang terkandung mengisyaratkan bahwa hakikah mengajarkan manusia bahwa ajaran islam yang dan perlu diketahui seluruh orang tua agar sejak bayi anak sudah diajarkan dan dan diperkenalkan dengan ajaran Islam.

Berdasarkan pengamatan peneliti, daging yang telah disembelih kemudian di masak lalu dihidangkan kepada para tamu untuk disantap. Sesuai informasi yang didapatkan bahwa salah satu makna Penyembelihan dan membagikan hewan sembelihan merupakan sedekah dan menjadi pelajaran dini dan doa bagi bayi yang baru lahir.

\section{Pelaksanaan Maccera}

a) mabacabaca

Ritual mabacabaca merupakan ritual wajib yang dilakukan oleh masyarakat Desa Paladang pada setiap pelaksanaan syukuran. Salah satunya pada pelaksanaan hakikah. Makna dari pelaksanaan mabacabaca adalah sebagai wujud rasa syukur dan rasa $\mathrm{p}$

Dalam ritual mabaca tersebut, cara pelaksanaannya tidak begitu rumit. Hanya membuat beberapa jenis makanan yang memang menjadi syarat dalam tradisi massuro Halaman $\mid 710$ 
baca. Makanan yang biasanya disiapkan adalah makanan-makanan tradisional, seperti onde-onde, baje, kue lapisi, dan lain-lain. Jenis kue ini sangat identik dengan tepung, gula merah dan kelapa yang dianggap sebagai filosofi kehidupan yang sejahtera. Juga sering dihidangkan makanan seperti nasi putih, beras ketan, lengkap dengan lauk seperti ayam, ikan, telur dan air putih. Makanan ini melekat filosofi kehidupan yang berkecukupan dan mapan.

Dalam ritual Mabbaca baca ini, pihak yang didoakan biasanya menyiapkan sajian makanan yang memiliki filosofi luas, dengan menggunakan nampang/baki di depan orang sesepuh itu dengan berbagai macam lauk pauk dan tak lupa beras ketan yang orang bugis katakan adalah sokko dan tidak lupa menyiapkan tungku kecil yang berisikan bara api dan kemenyan atau orang bugis menyebutnya dupa.

Masyarakat desa Paladang melaksanakan ritual ini adalah suatu bentuk dari rasa syukur yang kemudian di implementasikan dengan aksi nyata, disamping itu juga ritual ini bertujuan untuk mempererat tali silaturahim sesama keluarga dan tetangga.

\section{b) Barasanji}

Pembacaan kitab barasanji memiliki unsur agama yang harus dipahami oleh masyarakat. Masyarakat Desa Paladang umumnya membiasakan praktik pembacaan Barzanji dalam berbagai momentum, misalnya akikah, perkawinan, khitanan, khataman, syukuran, peringatan kematian ( $h a u l$ ), bagi orang yang ingin berangkat haji, dan banyak lagi momen dimana orang-orang berkumpul pada satu tempat. Mereka yang tinggal di daerah pedalaman, khususnya para orang tua, menganggap bahwasanya suatu acara tidak akan dilaksanakan dan tidak dianggap sah jika tidak dilakukan pembacaan Barazanji.

Bahwasanya akulturasi antara Islam dan budaya setempat dilakukan ketika substansi ajaran Islam tidak dirubah. Fleksibelitas ajaran Islam tergambar dalam banyaknya ajaran-ajaran Islam yang telah teakulturasikan dengan budaya setempat. Salah satunya adalah tradisi Barzanji.

Dapat dimaknai bahwa pembacaan Barzanji menjadi media dakwah dalam mengajarkan agama Islam lewat pembacaan kisah hidup Nabi Muhammad saw. sekaligus menumbuhkan rasa cinta terhadap Nabi saw. Tradisi pembacaan Barzanji pada masyarakat Massenrempulu khususnya di Desa Paladang biasanya dibaca dalam dua bahasa, bahasa Arab (bahasa asli Barzanji) dan terjemahannya dalam bahasa Bugis.

Pembacaan barazanji dilakukan juga pada saat rambut bayi dipotong sebagai wujud bahwa sibayi dapat mengikuti suri tauladan Nabi Muhammad saw dan mengikuti jejak kehidupan Rasulullah karena isi nyanyian barazanji adalah meceritakan tentang kehidupan Rasulullah.

Penggunaan buah kelapa sebagai tempat penyimpanan rambut bayi yang telah dipotong memiliki makna bahwa sebagai sutau pengharapan anak kelak bersifat seperti buah kelapa yang pohonnya memiliki manfaat dari akar sampai buah maka dalam hal ini anak diharapkan bisa bermanfaat bukan hanya untuk dirinya tetapi juga bermanfaat bagi orang-orang di sekelilingnya. Selain itu, makna buah kelapa mulai dari akar sampai buah memiliki makna yang baik, hal ini sebagai doa dan harapan bagi anak yang dilahirkan.

\section{c) sokko}

Sokko merupakan menu wajib pada saat melakukan bacabaca. Sokko atau lebih dikenal sebagi beras pulut atau ketan mempunyai makna tiap-tiap warna. Adapun makna dari setiap sokko tersebut adalah:

1) sokko pute berwarna putih adalah beras ketan yang memiliki makna bahwa manusia diciptakan berasal dari air

2) sokko maridi berwarna kuning adalah beras ketan yang memiliki makna bahwa manusia Halaman | 711 


\section{diciptakan dari angin}

3) sokko bolong berwarna hitam adalah beras ketan yang memiliki makna bahwa manusia diciptakan dari tanah

4) sokko macella berwarna merah adalah beras ketan yang memiliki makna bahwa manusia diciptakan dari api.

Makna yang terkandung dari sokko patarupa yakni agar kelak anak atau bayi yang dihakikah dapat menata kehidupannya dengan berbagai warna kehidupan.

Sokko pattarupa disajikan sebanyak empat piring dan dimasukkan ke dalam bala suji dengan makna bahwa angka empat sama dengan julah warna sokko sedangkan yang menyajikan sebanyak tujuh piring bermakna tujuh hari setelah kelahiran sibayi. Sokko pattarupa kemudian dimasukkan ke dalam balasuji sebagai sesajian yang akan diberikan kepada makhluk halus atau yang menjadi nenek moyang oleh masyarakat Desa Paladang.

Sesuai dengan hasil wawancara oleh informan:

" mabacabacaki sanga matarima kasihki pole ri Puangtaala sanga na bengangki dalle sibawa diberi kesehatang"

Dari hasil wawancara tersebut dapat diartikan bahwa mabacabaca dilakukan sebagai wujud ucapan rasa terima kasih kepada Allah SWT karena telah memberikan limpahan rezeki dan kesehatan.

\section{d) Balasuji}

Balasuji merupakan benda wajib yang harus ada pada pelaksanaan syukuran. Balasuji berasal dari pohon bambu yang telah dianyam berbentuk persegi empat. Yang dipercaya memiliki makna filosofi .

Pohon bambu adalah sejenis tumbuhan yang sangat berguna bagi kehidupan manusia. Ada satu sisi dari pohon bambu dapat dijadikan bahan pembelajaran bermakna, yakni pada saat proses pertumbuhannya. Pohon bambu ketika awal pertumbuhannya atau sebelum memunculkan tunas dan daunnya terlebih dahulu menyempurnakan struktur akarnya. Akar yang menunjang ke dasar bumi membuat bambu menjadi sebatang pohon yang sangat kuat, lentur, dan tidak patah sekalipun ditiup angin kencang. Metafora tersebut mengajarkan kepada manusia agar tumbuh, berkembang dan mencapai kesempurnaan bergerak dari dalam ke luar, bukan sebaliknya. Lebih jauh memahami filosofi pohon bambu tersebut, bahwa menjadi apa sesungguhnya kita ini sangat tergantung pada pemahaman, penghayatan, dan pengamalan kita tentang "Keimanan kepada Allah SWT yang terdapat dalam hati (qalbu) kita masing-masing.

Di dalam balasuji terdapat berbagai macam hasil bumi yang bisa dimanfaatkan sebagai dan memiliki makna. Adapun makanan yang disajikan mempunyai makna yakni:

a) telur yang disiapkan merupakan telur ayam kampung. Hal ini bermakna bahwa tradisi ini berasal dari orang tua terdahulu. Jumlah telur yang disajikan sebanyak sembilan biji. Empat biji telur memiliki makna bahwa manusia berasal dari tanah, air, api dan angin sedangkan lima biji telur mengandung makna bahwa Allah memciptakan manusia dengan memiliki indra perasaan, penciuman, pendengaran, penglihatan dan berbicara.

b) kalosi adalah buah pinang. Buah ini melambangkan bahwa anak atau sibayi dapat berjalan di jalan yang lurus sesuai dengan pohon pinang yang tinggi dan kokoh menjulang tinggi.

c) daun sirih diartikan sebagai malu dalam artian bahwa sibayi nantinya mempunyai rasa malu atau masyarakat desa lebih mengenal dengan kata siri.

d) pisang yang memiliki makna bahwa ketika berbuah maka harus ditebang pohonnya, agar tunas buah pisang dapat berbuah lagi, maka hal ini dimaksudkan agar anak atau 
sibayi dapat menghasilkan karya serta dapat menyelesaikan masalah walaupun ditimpa masalah.

e) kelapa yang disajikan adalah kelapa muda yang dinikmati langsung air dan isinya. Hal ini memiliki makna agar anak dapat bersifat seperti kelapa yang bermanfaat buat dirinya dan orang lain.

f) katupa" atau ketupat memiliki makna filosofi bahwa sibayi kelak tidak pergi ke tempat yang salah atu terpisah-pisah.

\section{e) Memakan sesajian}

orang tua dan anak memakan sesajian disiapkan dalam bentuk baki atau nampan makanan yang terdiri dari tujuh macam kue tradisional. Ketujuh macam kue tersebut merupakan keturunan orang tua terdahulu, yang memiliki rasa yang manis, maka bermakna bahwa agar kelak anak dapat memiliki kehidupan yang manis dalam menjalani kehidupannya di masa depan. Semua kue yang dimakan oleh anak, maka orang tua sianak harus memakannya. Hal ini memiliki makna bahwa agar anak kelak tidak durhaka kepada kedua orangtuanya.

\section{f) Balasuji dibawa ke sungai}

Pelaksanaan terakhir pada ritual ini yakni menghayutkan balasuji ke aliran sungai atau sumur. Menyerahkan sesajian untuk dialirkan ke sungai ataupun hanya sekadar hanya disimpan di samping sumur disertai dengan pembacaan mantra sebagi niat penyerahan sesajian kepada sang pencipta selanjutnya ibu dan anak dimandikan sebagai bukti pensucian setelah melahirkan agar terhindar dari segala bahaya yang akan menghampiri. Sesuai hasil wawancara yang didapatkan dari narasumber yakni:

"dipendio sianak sibawa indona supaya leppa manang sara-sarana".

Dari hasil wawancara tersebut dapat dideskripsikan bahwa narasumber mengatakan bahwa sianak dan ibu sianak harus dimandikan agar lunas semua hajatan yang telah dilaksanakan. Memandikan juga menandakan akhir dari sebuah sebuah prosesi atau ritual dan dimaknai sebagai salah satu penyucian diri bagi sibayi dan orang tua si bayi. 


\section{Simpulan}

Hasil penelitian menunjukkan bahwa prosesi yang dilakukan pada saat maccera pea merupakan prosesi yang telah dilakukan secara turun menurun oleh masyarakat Desa Paladang. Ada dua tahapan pada saat maccera pea yakni persiapan dan pelaksanaan prosesi adat. Setiap prosesi yang dilakukan mempunyai makna tersendri. Salah satu makna yang terkandung dalam tradisi ini, masyarakat Desa Paladang percaya bahwa setiap prosesi maccera pea sebagai wujud kerpercayaan atau keyakinan si anak yang diakikah akan memiliki keberkahan hidup untuk menjalani kehidupan. Pada aspek pragmatis dapat dimaknai bahwa tradisi ritual maccera pea memberikan faedah atau manfaat dalam kehidupan bermasyarakat. Kandungan nilai makna ritual ini dapat diaplikasikan ke dalam dunia nyata. Permohonan doa agar diberikan kesehatan dan limpahan rezeki sebagai wujud hubungan spritual manusia kepada sang pencipta.

Berbagai tanda (sign) dalam sebuah ritual memiliki interpretasi yang berbedabeda sehingga interpretan menafsirkan sebuah tanda yang dilihat berdasarkan penilaian subjektif dari masing- masing para penafsir. Begitu pula pada tanda dan makna yang ada pada ritual maccera pea. Ritual ini sebagai salah satu tradisi dan budaya sehingga menjadi aset keberagaman budaya yang ada di Indonesia khususnya yang ada di bumi Massenrempulu. 


\section{Daftar Pustaka}

Agustina, L. (2017). Analisis Semiotik dalam Kumpulan Cerpen Air Mata Ibuku dalam Semangkuk Sup Ayam. STILISTIKA: Jurnal Bahasa, Sastra, Dan Pengajarannya, 2(1), 54-63. https://doi.org/10.33654/sti.v2i1.378

Amandani, B. B., Ode, J. La, \& Masrul. (n.d.). Analisis Semiotik Ritual Tradisi "Haroa” Ptong Rambut (Aqiqah) pada Masyarakat Suku Buton di Kecamatan Kendari Varat Kota Kendari. 7(2), 1-16.

Djajasudarma, F. (2013). Relasi Makna, Paradigmatik, Sintagmatik dan Derivasional. Refika Aditama.

Kridalaksana, H. (2012). Kamus Linguistik. Gramedia.

Marhani, M. (2018). Nilai Budaya Mappano’ Dalam Pelaksanaan Aqiqah Pada Masyarakat Bulisu Kecamatan Batulappa. Al-MAIYYAH : Media Transformasi Gender Dalam Paradigma Sosial Keagamaan, 11(1), 1-29. https://doi.org/10.35905/almaiyyah.v11i1.540

Pradopo, R. D. (1999). Semiotika: Teori, Metode, Dan Penerapannya Dalam Pemaknaan Sastra. Jurnal Humaniora, Vol.11 No., 76-84.

http://portalgaruda.org/?ref=browse\&mod=viewarticle\&article=2865

Barthes, Roland. 2012. Elemen-elemen Semiologi. Yogyakarta: Jalasutra

Yoyon Mudijiono. (2011). Kajian Semiotika Dalam Film. Ilmu Komunikasi, 1(1), 123. 